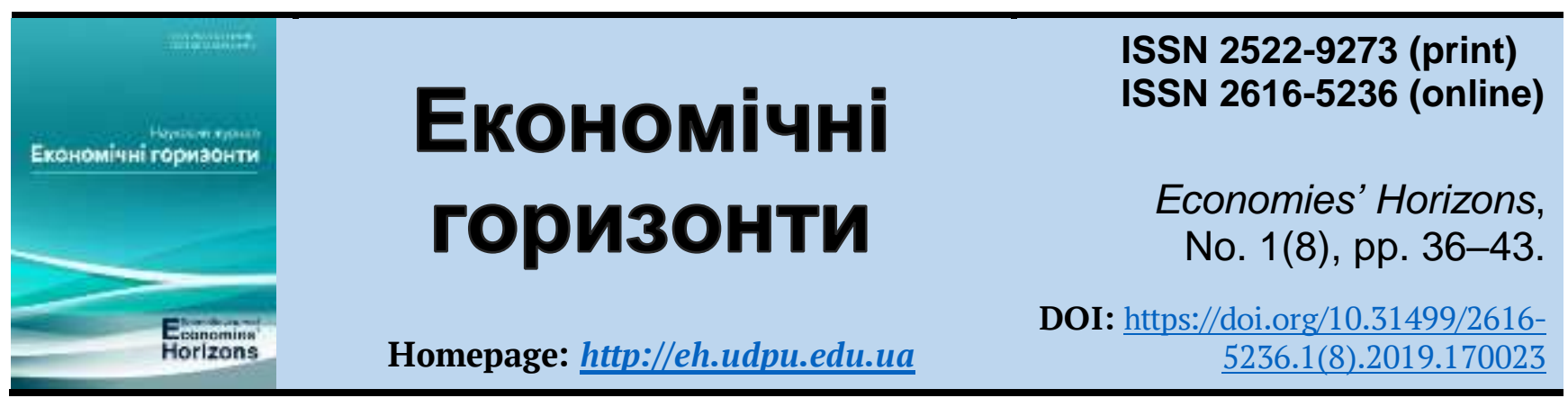

UDC 336.7

\title{
Application of systematic approaches to assessing the effectiveness of the bank in conditions of financial independence of the region
}

Received: 5 March 2019

Accepted: 10 April 2019

\author{
Yuliia M. Melnychuk ${ }^{1}$, Cand. Ec. Sc.
}

Melnychuk, Yu. M. (2019), "Application of systematic approaches to assessing the effectiveness of the bank in conditions of financial independence of the region", Economies' Horizons, no. 1(8), pp. 36-43, doi: https://doi.org/10.31499/2616$\underline{5236.1(8) .2019 .170023 . ~}$

Abstract. This article reveals the value of systematic approaches to assessing the effectiveness of banks in the conditions of financial independence of the region. The purpose of the research. The purpose of the study is to identify the main approaches to assessing the effectiveness of the bank in the conditions of financial independence of the region. Methodology. The totality of research methods is a methodology for analyzing and organizing the main legislative acts and laws, namely the methods of generalization, comparison, chronology, analysis and generalization. Results. The results of the study provide recommendations for the implementation of modern approaches to the financial performance of banks, in particular the justification of the approach to assessing the risk-taking efficiency of a bank and the need for a systematic approach to analysis and evaluation. This article summarizes the theoretical approaches to the essence of assessing the financial performance of the bank and justify the methodological principles of improving this process in the conditions of financial independence of the region. The international experience in assessing the effectiveness of the bank and its applicability to assess the effectiveness of Ukrainian banks is considered. Practical meaning. The results of the study can be used in the practice of banking institutions to self-check and assess the financial condition of the bank, seeking ways to improve its position in the banking market. Prospects for further research. On the basis of the conducted research there is an objective need to find out the theoretical and methodological bases of banks' activity for developing investment projects of the region's development with the attraction of capital of banking institutions.

Keywords: system approaches, performance appraisal, banking structures, financial independence, region.

JEL Classification: C 13, D 81, G 21, R 50

Number of references: 11; number of tables: 0; number of figures: $\mathbf{0}$; number of formulas: 3.

\footnotetext{
${ }^{1}$ Pavlo Tychyna Uman State Pedagogical University; Associate Professor at the Department of Finance, Accounting and Economic Security; ORCID ID: https://orcid.org/0000-0003-4149-0205; e-mail: melnichyk_yuliya@ukr.net.
} 
Melnychuk Yu. M. Application of systematic approaches to assessing the effectiveness of the bank in conditions of financial independence of the region

\section{Застосування системних підходів щодо оцінки ефективності діяльності банку в умовах фінансової незалежності регіону}

Стаття надійшла: 05.03.2019 Стаття прийнята: 10.04.2019

\author{
Ю. М. Мельничук ${ }^{1}$, к. е. н.
}

Melnychuk Yu. M. Application of systematic approaches to assessing the effectiveness of the bank in conditions of financial independence of the region. Економічні горизонти. 2019. № 1(8). C. 36-43. DOI: $10.31499 / 2616-$ $\underline{5236.1(8) .2019 .170023 .}$

Анотація. Стаття спрямована на аналіз системних підходів щодо оцінки ефективності діяльності банку в умовах фінансової незалежності регіону. Безумовно фінансовий сектор відіграє ключову роль у розподілі фінансових ресурсів в економіці. Ефективність банків має суттєвий вплив на економічну діяльність і значимість їі проявляється як на макро-, так i мікрорівні. В умовах формування незалежного регіону та їі ринкової фінансово-кредитної системи, конкурентоспроможності банківських послуг, продуктів перед банками постає завдання підвищення ефективності діяльності на основі впровадження оптимальних форм господарювання і управління банківською діяльністю. Особливе місце в цьому питанні посідає фінансовий аналіз діяльності банку, оскільки саме регулярне проведення банком аналізу дає можливість досягнення економічної ефективності функціонування банку. 3 урахуванням цього $\epsilon$ потреба у більш детальному теоретичному і методичному дослідженні аналізу та вибору системного підходу оцінки фінансово-економічної ефективності діяльності банку. Мета дослідження. Метою дослідження є виявлення основних підходів щодо оцінки ефективності діяльності банку в умовах фінансової незалежності регіону. Методологія. Сукупність методів дослідження становить методологію аналізу та організації основних законодавчих актів та законів, а саме методи узагальнення, порівняння, хронологізації, аналізу та узагальнення. Результати. За результатами дослідження надаються рекомендації щодо впровадження сучасних підходів оцінки фінансової ефективності діяльності банків, а саме обгрунтування підходу щодо оцінки ефективності діяльності банку з урахуванням ризику та необхідність застосування системного підходу. Узагальнено теоретичні підходи щодо сутності оцінки фінансової ефективності діяльності банку і обгрунтування методичних засад удосконалення даного процесу в умовах фінансової незалежності регіону. Розглядається міжнародний досвід оцінки ефективності банку і можливості застосування його для оцінки ефективності українських банків. Практичне значення. Результати дослідження можна використовувати у практичній діяльності банківських установ для самоперевірки та оцінки фінансового стану діяльності банку, пошуку напрямів покращення його позицій на ринку банківських послуг. Перспективи подальщих досліджень. На основі проведених досліджень виникає об'єктивна необхідність з'ясувати теоретичні та методологічні основи діяльності банків для розробки інвестиційних проектів розвитку регіону з залученням капіталу банківських установ.

Ключові слова: системні підходи, оцінка діяльності, банківські структури, фінансова незалежність, регіон.

Кількість джерел: 11; кількість таблиць: 0; кількість рисунків: 0; кількість формул: 3.

\footnotetext{
${ }^{1}$ Уманський державний педагогічний університет імені Павла Тичини; доцент кафедри фінансів, обліку та економічної безпеки; ідентифікатор ORCID: https://orcid.org/0000-0003-4149-0205; e-mail: melnichykyuliya@ukr.net.
} 


\section{Introduction.}

Investigating the theoretical basis of analysis and evaluation of the economic efficiency of the bank, the researchers identified the bank's economic efficiency as achieving the maximum profit size at the established level of risk. The methodological approaches to assessing the effectiveness are based on calculations of profitability coefficients, the socalled "classical indicators" of ROE, ROA and some others. It should be noted that all of the listed performance indicators do not take into account the concept of "profit-risk", and focus on calculations of only returns without taking risks. Recently, in the face of a sharp competition in the banking market of Ukraine in banks, there is a need for a better understanding of the economic efficiency of a variety of their business areas and decisions based on this understanding.

\section{Literature review.}

This problem is being studied by scientists, such as: I. Chmutova (2011), L. Prymostka (2014), L. Kovryzhenko (2016), H. Kalachova and O. Moiseienko (2017), E. Gataullina and L. Marshuk (2017), Yu. Melnychuk, O. Shkolenko, A. Gumeniuk and V. Melnik (2018), and others. At the same time, the issue of organizational and legal provision of insurance activity requires further research.

\section{Methods.}

The totality of research methods is a methodology for analyzing and organizing the main legislative acts and laws, namely the methods of generalization, comparison, chronology, analysis and generalization.

\section{Research objectives.}

The purpose of the study is to identify the main approaches to assessing the effectiveness of the bank in the conditions of financial independence of the region.

\section{Results and discussions.}

Since risks are an integral part of most banking business areas, the effective organization of the risk management process is one of the key competitive advantages of the bank. Therefore, it is advisable to consider one of the modern approaches to assessing the economic efficiency of a bank in the context of risk taking into account in the assessment of profitability (Risk-adjusted performance measurement - RAPM).

Methodology RAROC (Risk-adjusted return on capital) has become one of the most common models for such an assessment (Chugunov (ed.) and Lobanov (ed.), 2009). The development of the RAROC methodology began at the end of the 1970s at the initiative of the group Bankers Trust. The initial idea was to determine the risk of a bank's loan portfolio, as well as the amount of equity needed to cover potential losses both to depositors of the bank and lenders. That is, RAROC is a risk-adjusted concept for assessing profitability and managing the bank's performance.

The general view of the risk-based efficiency assessment can be summarized as follows:

RAPM $=\frac{\text { Financial result of bank activity }}{\text { Risk }}$

where RAPM - risk-based income.

The risk is a quantitative estimate of the potential (maximum possible) losses that may be incurred by a separate business area that carries out a specified financial activity. For the bank as a whole, these losses should not exceed the capital of the bank, because nonfulfillment of this condition will lead to a financial instability of the bank. But the risk of a financial institution as a whole consists of risks that take on business lines. Therefore, in order to assess each business direction, it is necessary to quantify the risk that is being taken by them. In other words, it is necessary to distribute the capital of the entire bank for each business line in accordance with the riskiness of its financial transactions. In order to concentrate in business areas only the risks inherent to them, redistribution of risks is carried out through the use of internal transfer pricing.

It should be noted that the application of this model is suitable for a comprehensive assessment of the bank's performance, that is, 
both in the context of the bank, and in the context of business areas, divisions, banking products and client groups. In any case, the idea is one: it is the ratio of net profit from the unit's activities, from the product or client to the risk of the transaction, but not to the share of the capital employed (as in the ROE), or the share of operations in the total asset portfolio (as in ROA).

Net profit (NP) from banking operations is the proceeds from the transaction $(\mathrm{P})$ less provision for the loan (PL), interest expense for financing the transaction (EF), operating expenses (OE), and income tax (IT):

$$
\mathrm{NP}=\mathrm{P}-\mathrm{PL}-\mathrm{EF}-\mathrm{OE}-\mathrm{IT} .
$$

In monetary terms, the risk is expressed through economic capital (EC) - this is part of the assets of the bank, which is in the most liquid form to cover unforeseen costs. Accordingly, the formula for calculating the risk-taking returns looks like:

$$
\text { RAROC }=\text { PU } / \text { EU, }
$$

where RAROC - risk-based returns;

PU - net profit unit, operations;

EC - economic capital.

Considering the possibility of applying the RAROC methodology in assessing the economic efficiency of the bank, it should be noted that the calculation of risk-based returns implies the existence of two components - the calculation of profitability and calculation of risks.

With regard to the calculation of profitability, then the bank must have a system of managerial accounting, which will allow the calculation of profitability by divisions, products and customers. Such a system needs to be implemented:

- asset and liability management and budgeting systems for the distribution of direct income and expenses of units;

- transfer pricing systems for the distribution of interest income;
- systems for distributing overheads and presentation of internal accounts.

Unfortunately, to date, most banks have problems in this area, such as the unclear definition of profit and expenditure centers, a simplified or completely missing transfer pricing system, etc.

Regarding the calculation of risks, traditionally, risk management systems in Ukrainian banks focus on risk protection, that is, the use of limits, and almost no such thing as "calculation of economic capital for risks". Taking into account the recommendations of the Basel Committee for assessing market risks (Basel I) and for credit and operational risks (Basel II), the following requirements for the calculation of economic capital (Basel II) should be ensured:

- the assessment of the economic capital for market, credit and operational risks should be aligned, that is conducted within the framework of one general methodology;

- it is desirable that, in addition to calculating the economic capital, the methodology chosen gave the opportunity to calculate the limits, as well as the scenario method, stress testing, sensitivity analysis.

The most optimal way to calculate economic capital for market risks is to use the "Internal Market Based Approach" recommended by the Basel Committee. In accordance with this approach, for the calculation of economic capital, the value-at-risk (VaR) value is taken, that is, the size of maximum portfolio losses for a certain period of time at a certain probability level. Regarding the calculation of economic capital for credit risks and operational, it is recommended to use an approach based on internal ratings and estimates of the bank.

According to national legislation, the bank should ensure systematic risk analysis aimed at their detection and assessment of their magnitude. The purpose of the analysis should be to understand the nature of the risks faced by the bank and determine whether they are consistent with its objectives, strategy and policy. Therefore, such an analysis should be 
carried out continuously both at the level of the institution as a whole and at the level of the individual units and should include the identification, measurement and evaluation of all types of risks, including the relationship and the mutual influence between the different risk categories.

For more effective market risk management, it is recommended: 1 ) to prepare reliable data and effective methods such as Risk Assessment (VAR), stress-testing to assess the nature and value of market positions of the bank and to assess the level of market risk that the bank is exposed to or exposed to; 2) apply back-testing to compare with the actual results of evaluations and assumptions made using the data and techniques mentioned above (Basel Committee on Banking Supervision, 2004).

Regarding effective credit risk management, it is recommended:

- to create, put into operation and constantly update the system of internal credit ratings;

- based on real observations, quarterly calculate the matrix of the probabilities of migration of credit ratings and estimate on the basis of such a matrix the amount of necessary reserves for credit losses in subsequent periods;

- conduct back-testing of migration of internal credit ratings on real data for the maximum possible period of time.

The need to build a risk-based returns system is beyond doubt. The main competitive advantages of the bank when applying this method are as follows:

- strategic planning of risk-taking activities of the bank;

- adequate assessment of banking products and identification of promising areas; bank;

- growth of the rating and image of the

- calculation of economic efficiency of subdivisions and use of results for building a system of personnel motivation;

- growth of internal corporate culture and professionalism (National Bank of Ukraine, 2004).
A systemic approach to the analysis of the efficiency of a commercial bank should take into account a balanced system of indicators that take into account all the essential aspects of its activities. A balanced system of indicators will allow conducting a comprehensive analysis of interconnections within the bank, timely track both positive and negative changes in various spheres of governance and influence them. The main difference between the balanced system of performance indicators from an arbitrary set of indicators is that all indicators are oriented on the strategic goals and objectives of the bank, and are interrelated and grouped according to certain features ( $\mathrm{Ni}$ kitina, 2004, p. 18).

Taking into account that in Ukraine there is no sufficiently substantiated theoretically methodology for assessing banking activity in terms of providing a comprehensive assessment of the efficiency of banks, we outline the most significant characteristics of banks' activities that need to be taken into account when assessing the economic efficiency of banking institutions: capital sustainability, commercial, organizational, functional and financial stability. Since the approach that is becoming more and more popular in recent times, when the bank is viewed as an economic system, and its effectiveness is defined as the reliability and stability of relations between its elements, so the sustainability index can be considered an integral indicator of economic efficiency.

Considering capital sustainability as one of the necessary components of economic efficiency, it should be noted that the basis of the capital's stability is the volume of equity, which provides a sufficient amount of funds, which can be used if necessary to repay deposits, to create a provision for repayment of unforeseen losses or debts. Equity is also a source of financing for the development of the bank, overcoming the negative situations caused by force majeure, the key to the necessary response to the financial market situation.

The commercial stability of the bank is expressed by: the level of bank ties with other subjects of the market infrastructure, the 
development and strength of relations with the state; Integration into the system of inter-bank relations; quality of cooperation with creditors, debtors, clients and depositors; the dependence of the banking sector on the state of the economy as a whole; the strength of the link between the volume of the bank's cash capital and its real capital; concentration of the share of assets and private deposits at the disposal of one financial institution; control of a significant amount of financial flows in a country.

Regarding the organizational and structural stability of the bank, then it and the mechanism of its management should correspond both to the implementation of the main function of the financial and credit institution, and to the specific range of banking services and products underlying the tactics and strategy of the bank. The organizational and structural stability of the commercial bank is defined by the functional and technical documentation, which regulates all aspects of its activities, which concern both the organizational structure and specific banking operations.

Functional stability of the bank. First of all, it depends on the level of specialization of the bank in a limited range of services and products, which enables a specialized bank to manage its own and attracted capital more rationally and efficiently. Second, the universalization of the bank (or expansion of its operations) also leads to increased functional stability, as it contributes to the fact that many customers have the opportunity to satisfy the entire range of their needs for banking services and products in one bank. Both the first and the second of these criteria for determining the functional stability of the bank and its management have both positive and negative aspects. Thus, the high level of specialization of a conominal bank enhances its dependence on changes in the market conditions in commodity and credit markets and creates obstacles for the possibility of expansion of banking operations in difficult situations for the bank.

When investigating the financial stability of the bank, it should be noted that this characteristic of the activities of the bank contains the above basic indicators that synthesize the effectiveness of other components of the stability of the financial institution, primarily the volume and structure of their own funds, the level of profitability and profitability, the rate of return on equity, observance of established indicators of liquidity, the efficiency of equity capital, the amount of value added created. The Bank maintains financial stability allows it to remain competitive on the lending market. However, this is a very difficult task.

The considered components of the stability of a commercial bank are not independent and are closely interrelated. For example, capital and financial stability are inseparable, especially when the bank is operating for several years. Functional and commercial sustainability is also associated. That is, these components should be considered as the main interrelated areas for analysis, rather than as separate components.

The application of a systematic approach to assessing the economic efficiency of a bank's activity implies, in addition to the allocation of components of efficiency, as well as a set of indicators for the evaluation of these components. Thus, Annex A provides a set of indicators that we believe should be used when assessing the bank's capital adequacy. But it should be noted that the recommended value of these indicators will depend, above all, on the type and purpose of the analysis (internal or external); and in the case of internal analysis, it is from the bank's strategy, which will be characterized by an aggressive, moderate or conservative model.

As to the financial stability of the bank, the use of such indicators as business activity and liquidity is substantiated in the economic literature; but the consideration of these indicators, in our opinion, is more important when considering the topic of assessing the financial condition of the bank, so we consider it inappropriate to consider these indicators.

In addition to the considered indicators, the systemic approach to assessing the 
economic efficiency of the bank can include factors that determine the effectiveness of bank employees (Parasii-Vergunenko, 2003). These factors include productivity and cost-effectiveness of personnel. Since labor remuneration is the most important component of noninterest-bearing expenses of the bank, the productivity of the work of the bank's employees, which is measured by the number of staff and expenses for its maintenance, can indicate the effectiveness of the institution itself. However, the productivity of work should be evaluated, taking into account the fact that at the current time, saving on wages (due to its considerable reduction or decrease in the number of employees) can lead to deterioration of quality and weakening of motivation to work, and eventually to decrease the efficiency of the bank. Labor productivity shows how much net profit was earned in the period under study per employee. The cost-effectiveness of staff costs measures the payback of staff costs, demonstrates the net effect of employee motivation decisions regardless of whether these decisions are aimed at low qualifications and low wages or high costs for highly skilled workers. It is determined by the ratio of net profit to personnel costs.

Thus, the effectiveness of the bank is not only the results of its activities, but also the management system, which should be based on the formation of a scientifically grounded strategy of activities using modern approaches that reflect the financial independence of the region.

\section{Conclusions.}

The study of the analysis and evaluation of financial efficiency of the bank enabled theoretically to substantiate and develop recommendations and proposals aimed at solving a number of problems.

The financial efficiency of the bank should be understood as the achievement of the maximum profit size with the established risk level acceptable for a particular bank. It is clear that each banking institution will have its own level of economic efficiency, which will depend on the selected strategy.
Taking into account the peculiarities of banking activity, we have concluded that the analysis and evaluation of the bank's economic efficiency can not focus only on the definition of profit and profitability indicators. It is necessary to determine at the expense of which a separate amount of profit is achieved. Need to know the ratio of own and borrowed resources; does the authorized capital of the functions assigned to it; qualitative structure of assets and liabilities; what level of risk (credit, currency, and interest) accompanies the receipt of profit. In addition, it was concluded that the effective functioning of the bank depends on the quality of the analysis of the activity on the basis of all available data for analysis, and on the basis of an analysis of all aspects of the bank's activities.

Having examined the international experience in assessing the economic efficiency of the bank, these performance indicators were identified from the perspective of shareholders. Therefore, "system of balanced indicators" is considered as a system of not only financial indicators as one of the main criteria for evaluating the performance of the organization (the bank), but also as a system of nonfinancial indicators that assess the satisfaction of buyers and shareholders, the efficiency of internal business processes, potential employees in order to ensure long-term financial success of the company. Therefore, it is expedient to study this system of balanced indicators, which enables to manage the bank's efficiency in the long run and adapt to the Ukrainian banks functioning features.

Investigating the theoretical basis for the analysis and evaluation of the economic efficiency of the bank, we determined that the methodological approaches to the assessment of efficiency based on calculations of profitability coefficients (ROE, ROA, "classical indicators") which do not take into account the concept of "profit-risk", and focus on calculations of only returns without taking into account risks. Therefore, in our opinion, Ukrainian banks need to consider the possibility of using the RAROC model as a risk-adjusted 
concept for assessing profitability and managing the bank's efficiency.

It also proposes the use of a systematic approach to assessing the effectiveness of the bank, which will allow a comprehensive analysis of interconnections within the bank, to track both positive and negative changes in various areas of management in a timely manner and to influence them. The main feature of this system of indicators is that all indicators are oriented on the strategic goals and objectives of the bank, and are interrelated and grouped according to certain features.

Therefore, for the functioning of a financially independent region, it is important to make significant changes in the organization and activities of all entities in the region's infrastructure. The banking system also needs innovation. Therefore, one of the elements of the reorganization of the infrastructure may be changes in the assessment and analysis of banking activities.

\section{References}

Basel Committee on Banking Supervision (2004), Basel II: International Convergence of Capital Measurement and Capital Standards, Bank for International Settlements Press \& Communications, Basel, Switzerland, $239 \mathrm{p}$.

Chmutova, I. M. (2011), “Features of the functioning of state banks in the banking system of Ukraine”, Problemy Ekonomiky, no. 4, pp. 135-138.

Chugunov, A. V. (ed.) and Lobanov, A. A. (ed.) (2009), Jenciklopedija finansovogo risk-menedzhmenta [Encyclopedia of financial risk management], Al'pina Pablisher, Moscow, Russia, 878 p.

Gataullina, E. I. and Marshuk, L. N. (2017), “Analysis of performance of commercial banks indicators is in Ukraine”, Ekonomika ta Suspilstvo, no. 12, pp. 515-521.

Kalachova, H. and Moiseienko, O. (2017), "What will happen to Sberbank, Privatbank and Ukrhasbank until 2022? Draft strategy”, Ekonomichna Pravda, available at: https://www.epravda.com.ua/publications/2017/12/27/632572/ (Accessed 3 March 2019).

Kovryzhenko, L. O. (2016), "State Bank: international experience and perspectives for Ukraine”, Visnyk Khmelnytskoho natsionalnoho universytetu, vol. 1(2), pp. 126-128.

Melnychuk, Yu. M., Shkolenko, O. B., Gumeniuk, A. V. and Melnik, V. V. (2018), "Bank deposit as a direction of investment activity's activation of insurers in life insurance", Financial and Credit Activity: Problems of Theory and Practice, vol. 4(27), pp. 41-48, doi: https://doi.org/10.18371/fcaptp.v4i27.154008.

National Bank of Ukraine (2004), "Guidelines for the organization and functioning of the risk management system in banks of Ukraine”, available at: https:/bank.gov.ua/control/uk/publish/category?cat id=45294 (Accessed 3 March 2019).

Nikitina, T. V. (2002), Bankovskij menedzhment [Banking Management], Piter, St. Petersburg, Russia, 160 p. Parasii-Vergunenko, I. M. (2003), Analiz bankivskoi diialnosti [Banking analysis], KNEU, Kyiv, Ukraine, 347 p. Prymostka, L. O. (2014), "State capital in the banking system of Ukraine”, Finansy, oblik i audyt, vol. 2(24), pp. 107-119.

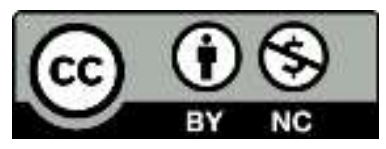

Цей твір ліцензовано на умовах Ліцензії Creative Commons «/з Зазначенням Авторства - Некомериійна 4.0 Міжнародна» (CC BY-NC 4.0). This is an open access journal and all published articles are licensed under a Creative Commons "Attribution-NonCommercial 4.0 International" (CC BY-NC 4.0). 